\title{
A PERCEPTIONAL ANALYSIS OF BANKING EMPLOYEES ON
}

\section{ORGANIZATIONAL CLIMATE}

\section{A Comparative Study among Public and Private Sector Banks}

\section{B. NAGARAJU ${ }^{1} \&$ POOJA $\mathbf{J}^{2}$}

${ }^{I}$ Chairman and Professor, DoS in Commerce, Manasagangotri, University of Mysore, Mysore, Karnataka, India

${ }^{2}$ Research Scholar, DoS in Commerce, Manasagangotri, University of Mysore, Mysore, Karnataka, India

Organizational climate determines the employee's perception as well as perspectives of an organization. The present study makes an attempt to examine the organizational climate in banking Industries through the organizational climate dimensions which are more pervasive. It has been empirically proved in many Indian and Western organizations that employee-centered climate and achievement oriented climate ultimately improve performance. The study was conducted to compare the organizational climate as perceived by employees working in public and private sector banks. The sample consisted of 150 employees, out of 150, 92 employees are from public sector bank and 58 employees are from private sector banks. The data obtained was analyzed using means, S.D's and ANOVA. Findings of the study indicated that organizational climate is significantly different in public and private sector banks. The study revealed that, the centralized authority in the organization motivates employees; organizational climate motivates employees and makes them feel part of the organization. Employees gain adequate training related to their job and to meet professional standards, Training and development enhances the efficiency and effectiveness of the work being performed by employees is significantly higher in case of private sector bank employees. The valid conclusions based on such an investigation would result in suggestions for bringing about a perception affecting organizational climate in public and private sector banks. Further it stimulates thinking among researchers on dimensions to be incorporated in a study of organizational climate.
\end{abstract}

KEYWORDS: Organizational Climate, Public Sector, Private Sector \& Employees

Received: Jul 10, 2017; Accepted: Jul 31, 2017; Published: Aug 05, 2017; Paper Id.: IJHRMRAUG20174

\section{INTRODUCTION}

Organizational climate is an important aspect of organization and management. The increasing research in this field and the concentrated deliberations on the subject contributed to its conceptualization and meaning which helped to develop a wide-ranging outlook of organizational climate as an important concept. Organizational climate is the shared perception of employees who work and subsist in the organization. It is the sum of individual perceptions regarding the organizational procedures, policies and practices .It is the set of measurable properties of the work environment, perceived directly or indirectly by the members, influencing their work and satisfaction. Organizational Climate is about the perceptions of the climate and about complete measures. The 'Climate' may be regarded in absolute terms and measured by instruments, but is 'felt' differently by individuals. The absolute climate may suit one person and not another. All organizational theoreticians and researchers collectively agree that a social Climate is extremely important for the ultimate achievement of organizational goals. Organizational Climate is comprised of a combination of norms, values, expectations, policies and procedures that influence work motivation, 
commitment and ultimately individual or work unit performance.

\section{CONCEPT OF ORGANIZATIONAL CLIMATE}

Organizational climate defines the perceptions employees have about the environment of an organization. Campbellet, defines organizational climate is defined as a set of attributes specific to a particular organization that may be induced from the way that organization deals with its members and its environment. Researches on organizational climate have used data relating to individual perception on organizational properties identifying organizational climate. According to Hellreigel and Slocum (1974), organizational climate is a set of perceived attributes of the organization (or its sub systems), induced from the way the organization and its members deal with each other and with their environment. Organizational climate is a set of global perceptions, held by organizational members about their organizational environment. Schneider and Hall (1972) Reichers \& schneider, (1990) Organizational climate is defined as shared perceptions or prevailing organizational norms for conducting workplace activities .Cooper (2003) describes organizational climate as "people's perception of their working environment with regard to caring and friendliness." Gerber (2003) and Moran and Volkwein (1992) were integrated. Organizational climate is defined as the shared perceptions, feelings and attitudes that organizational members have about the fundamental elements of the organization, which reflect the established norms, values and attitudes of the organization's culture and influences individual's behavior positively or negatively.

\section{LITERATURE REVIEW}

Pratap et.al. (1985) in his article entitled "Relationship between Job Satisfaction and Organizational Climate; Study of Public Sector: Undertaking in Uttar Pradesh", revealed that there was a significant difference between the private and public sector industries in organizational climate. It was found that organizational climate in private textile industry was perceived to be autocratic and that of public textile industry democratic.

Akhilesh et.al. (1986)in their article entitled "A Comparative Study of Organizational Climate in Two Banks" they stated that evidence available indicating that organizational climate is associated with occupant's positive effect towards job climate dimensions and is related to employee performance.

Dawson (1987) in his work "Computer Technology and the Job of the First-Line Supervisor" Focus on demographic determinants of workers job satisfaction but, the others relate it with nature of work and working conditions at the workplace. Similarly, fair promotion system in the organization, job autonomy, leadership behavior, social relations and the job itself are also among the important factors of job satisfaction.

Park (2001) in his study entitled "Relationship between Job Satisfaction and Organizational Climate; Study of Public Sector: Undertaking in Uttar Pradesh", in their study revealed that there is significant correlation between organizational climate and job satisfaction institution.

Gani (2001) in their research article "Correlates of organizational climate in banking industry" provides an adequate description of the concept, constructs, determinants and correlates of organizational climate. Study also indicated that the organizational climate in banking industry, as a whole, has an inadequately perceived and that the institution in the private sector banks is inferior to that of the public sector ones.

Klien K. J., (2001) in his work entitled "Is everyone in agreement? An exploration of within-group agreement in 
employee perceptions of the work environment" Climate consists of a set of characteristics that describe an organization, distinguish it from other organizations, are relatively stable over time and influence the behavior of people in it. The individual worker's perception of his work environment rather than a consent view is considered, as different individuals may perceive the same workplace in different ways.

Rizzatti (2002), study entitled "Categorias de análise de clima organizacional em universidades federais brasileiras" the study of the organizational climate is a tool capable of detecting deficiencies in the structure and anomalies in the working environment. The author states that the study of the climate is a potentially strong tool to improve the quality of the organization.

Purang (2006) in his research article entitled "Dimensions of HRD climate enhancing organizational commitment in Indian organizations" reported HRD Climate perception of employees in private and multinational organizations to be significantly better than in public sector organizations.

Butt, et.al. (2012) in their study "A Comparative Study of Organizational Climate and Job Satisfaction in Public, Private and Foreign Banks" found that, the overall perception about organizational climate at SCB (Standard Chartered Bank) has turned out to be most favorable of all the three banks, under consideration. Whereas, the organizational climate at MCB (Muslim Commercial Bank) and NBP (National Bank of Pakistan), are perceived to be relatively less favorable. Furthermore, the perception of NBP"es organizational climate stood out to be least favorable.

\section{STATEMENT OF THE PROBLEM}

Organisational climate affects every activity in an organization directly or indirectly. The growth of an organization is directly related to the climate. One of the key factors that may influence on employees' perception is organisational climate. Organisational climate helps to set the quality of the organization .The present study makes an attempt to examine the organizational climate prevailing in public and private sector banks through the organizational climate dimensions which are more widespread. It has been empirically proved in many Indian and Western organizations that employee-centered climate and achievement oriented climate ultimately improve performance. In this context, it seems sensible to undertake an investigation into organizational climate. The valid conclusions based on such an investigation would result in developing suggestions for bringing about a work environment, motivational and training \& development are essential for scaling new heights in employee productivity in banking sector. Further it encourages thinking among researchers on dimensions to be incorporated in a study of organizational climate.

\section{NEED FOR THE STUDY}

Banking participate an essential part in the well-organized use of national assets through loan, investing and transferring money all over the nation and even among countries. Role of banking is crucial in a developing country. Recently the Indian economy has witnessed the emergence of many banks in the private sector. There are several reasons behind the increasing number of commercialization of banks. The growth of such banks is not possible unless they witness some success in the context of customer satisfaction or may it be the net assets held by these banks, efficiency of their management or the networks of each bank both in private as well as the public sector bank. The present study has undertaken to make a comparative analysis between public and private sector banks influencing organizational variables on climate perception. As earlier studies reveals that climate varies from organization to organization. So, every organization has to be attentive towards their organizational climate. The present study has made an attempt to find is there any 
significant changes in organizational climate on perception of respondents.

\section{OBJECTIVES OF THE STUDY}

- To examine the perception of employees towards their working environment with respect to organizational climate in public and private sector banks.

- To investigate the perception of employees towards motivation with respect to organizational climate in public and private sector banks.

- To analyze perception level of employees on training and development with respect to organizational climate in public and private sector banks.

\section{HYPOTHESES OF THE STUDY}

H0: There is no significant difference between the employees of public and private sector banks with respect to work environment.

H1: There is a significant difference between the employees of public and private sector banks with respect to work environment.

H0: There is no significant difference between the employees of public and private sector banks with respect to Motivation.

H2: There is a significant difference between the employees of public and private sector banks with respect to Motivation.

H0: There is no significant difference between the employees of public and private sector banks with respect to Training and development.

H3: There is a significant difference between the employees of public and private sector banks with respect to training and development.

\section{METHODOLOGY}

\section{Research Design}

The descriptive survey research is considered suitable for the present study. The reason for selecting the descriptive method of research was that it helps in generality to a greater extent than the experimental research design.

\section{Sources of Data}

The study utilized both primary and secondary sources for collecting data. The primary sources of data collections done with the help of administration of structured questionnaire and secondary sources are journals, books, reports and records, $\mathrm{PhD}$ Thesis and internet sources.

\section{Population and Sample Size of the Study}

This study was carried out among both public and private sector bank employees. The sample selection was totally random without any bias. 150 employees are randomly selected from which 92 are from public sector bank employees and 58 are from private sector employees are the respondents of the structured questionnaire. Perception of the 
employees on organizational climate was collected through structured questionnaire on a five point Likert Scale as "Strongly disagree "to "strongly agree" and rating given as 1 to 5 respectively.

\section{Tools of Data Analysis}

In this study data analysis is performed with the help of Statistical Package for Social Sciences (SPSS 19 version). The study used both descriptive as well as inferential statistics to represent the responses. Hypothesis testing is done using, ANOVA for large samples.

Balance ANOVA is used for analysis purpose, because the data collected are further sampled as two different populations i.e., Public Sector Banks and Private Sector Banks.

\section{Reliability Test}

To test the reliability of the data collected, Cronbach's Alpha test is used and its value is found to be 0.957 which is more than the standard norm (0.07). SPSS produces many different tables. The Reliability Statistics table provides the actual value for Cronbach's alpha, as shown in Table-1.

Table 1

\begin{tabular}{|c|c|}
\hline \multicolumn{2}{|l|}{ Reliability statistics } \\
\hline Cronbach's Alpha & Number of items \\
\hline .957 & 15 \\
\hline
\end{tabular}

Source: Primary data

\section{Work Environment Factor}

H0: There is no significant difference between the employees of public and private sector banks with respect to work environment.H1: There is a significant difference between the employees of public and private sector banks with respect to work environment

Table 2: Showing Descriptive Statistics for Work Environment

\begin{tabular}{|l|l|c|c|c|}
\hline & & N & Mean & Std. Deviation \\
\hline \multirow{2}{*}{$\begin{array}{l}\text { A good lighting system increases } \\
\text { employee's productivity. }\end{array}$} & Public sector & 92 & 4.2391 & .88168 \\
\cline { 2 - 5 } & Private sector & 58 & 3.9138 & .96035 \\
\cline { 2 - 5 } & Total & 150 & 4.1133 & .92349 \\
\hline $\begin{array}{l}\text { Controlled noise and temperature in } \\
\text { work place will make an employee to } \\
\text { concentrate on their job }\end{array}$ & Public sector & 92 & 4.2609 & .93608 \\
\cline { 2 - 5 } & Private sector & 58 & 3.9138 & .94190 \\
\cline { 2 - 5 } $\begin{array}{l}\text { Work area has a safe working } \\
\text { environment. }\end{array}$ & Total & 150 & 4.1267 & .95043 \\
\cline { 2 - 5 } & Public sector & 92 & 4.2500 & .76496 \\
\cline { 2 - 5 } & Private sector & 58 & 3.9483 & .90655 \\
\cline { 2 - 5 } & Total & 150 & 4.1333 & .83277 \\
\hline
\end{tabular}

Table 3: ANOVA for Work Environment

\begin{tabular}{|c|l|c|c|c|c|c|}
\hline & & Sum of Squares & df & Mean Square & F & Sig. \\
\hline \multirow{4}{*}{ WE2 } & Between Groups & 3.751 & 1 & 3.751 & 5.800 & .017 \\
\cline { 2 - 8 } & Within Groups & 95.704 & 148 & .647 & & \\
\cline { 2 - 8 } & Total & 99.455 & 149 & & & \\
\hline
\end{tabular}

Employee's productivity is increased by a good lighting system and shows that there is a significant difference between the employees of public and private banks. The mean value is 4.2391 indicating that public sector employees have 
higher aspiration in this regard.

With respect to, 'Controlled noise and temperature in the workplace will make an employee to concentrate on their job' is comparatively more in case of public sector employees with a mean value of 4.2609.

Public sector employees mean value of 4.2500 highlights that their 'Work area has a safe working environment'.

While examining the perception of the employees towards their work environment with respect to organizational climate, Null hypothesis stating there is no significant difference, between the employees of public and private sector banks, with respect to work environment.

\section{Motivational Factor}

H0: There is no significant difference between the employees of public and private sector banks with respect to Motivation.

$\mathrm{H} 2$ : There is a significant difference between the employees of public and private sector banks with respect to Motivation.

Table 4: Showing Descriptive Statistics for Motivation

\begin{tabular}{|c|c|c|c|c|}
\hline & & $\mathbf{N}$ & Mean & $\begin{array}{c}\text { Std. } \\
\text { Deviation }\end{array}$ \\
\hline \multirow{3}{*}{$\begin{array}{l}\text { Employee's level of motivation is influenced by their co- } \\
\text { employee's co-operation and support from superiors. }\end{array}$} & Public sector & 92 & 4.1196 & .70854 \\
\hline & Private sector & 58 & 4.2414 & .75650 \\
\hline & Total & 150 & 4.1667 & .72738 \\
\hline \multirow{3}{*}{$\begin{array}{l}\text { The quality of working environment and working condition at } \\
\text { the organization has an influence on motivation. }\end{array}$} & Public sector & 92 & 3.7500 & .87235 \\
\hline & Private sector & 58 & 3.9310 & .79167 \\
\hline & Total & 150 & 3.8200 & .84401 \\
\hline \multirow{3}{*}{ Nature of job influences employee's level of motivation. } & Public sector & 92 & 3.9130 & .99064 \\
\hline & Private sector & 58 & 4.1034 & .83118 \\
\hline & Total & 150 & 3.9867 & .93397 \\
\hline \multirow{3}{*}{ Employees have a feeling of self-esteem on their job. } & Public sector & 92 & 4.0217 & .79805 \\
\hline & Private sector & 58 & 4.3793 & .67089 \\
\hline & Total & 150 & 4.1600 & .76921 \\
\hline \multirow{3}{*}{$\begin{array}{l}\text { The centralized authority in the organization motivates } \\
\text { employee's efficiency. }\end{array}$} & Public sector & 92 & 3.7717 & .97331 \\
\hline & Private sector & 58 & 4.0690 & .85557 \\
\hline & Total & 150 & 3.8867 & .93792 \\
\hline \multirow{3}{*}{$\begin{array}{l}\text { Organizational climate motivate employees and } \\
\text { Makes them feel part of the organization. }\end{array}$} & Public sector & 92 & 3.9022 & .99515 \\
\hline & Private sector & 58 & 4.2241 & .99195 \\
\hline & Total & 150 & 4.0267 & 1.00299 \\
\hline
\end{tabular}

Source: Primary data

Table 5: ANOVA for Motivation

\begin{tabular}{|c|l|c|c|c|c|c|}
\hline & & Sum of Squares & df & Mean Square & F & Sig. \\
\hline \multirow{3}{*}{ MOT } & Between Groups & 2.135 & 1 & 2.135 & 3.987 & .048 \\
\cline { 2 - 8 } & Within Groups & 79.272 & 148 & .536 & & \\
\cline { 2 - 8 } & Total & 81.408 & 149 & & & \\
\hline
\end{tabular}

Employee's level of motivation is influenced by their co- employee's co-operation and support from superiors is more in case of private sector employees with a mean value of 4.2414 .

The quality of working environment and working condition at the organization has more influence on motivation 
in private sector banks showing a mean value of 3.9310 .

Private sector employees are showed more mean value of 4.1034 for 'Nature of job which influences employee's level of motivation'.

Employees have a feeling of self -esteem on their job shows a significant difference between the sectors seeking a higher mean in case of private sector which is 4.3793

There was significant difference among the sectors with respect to 'The centralized authority in the organization motivates employees' having a mean of 4.0690, resulting towards Private sector employees is motivated with more centralized authority.

With reference to organizational climate motivates employees and makes them feel part of the organization found to have a significant difference between the sectors indicating the mean value of 4.2241 in private sector banks.

Summary of ANOVA for motivation reveals that there is a significant difference between public sector and private sector employee's .Hence the Null hypotheses stating that

'There is no significant difference between the employees of public and private sector banks with respect to Motivation' is rejected.

\section{Training and Developmental Factors}

H0: There is no significant difference between the employees of public and private sector banks with respect to Training and development.

H3: There is a significant difference between the employees of public and private sector banks with respect to training and development

Table 6: Showing Descriptive Statistics for Training and Development

\begin{tabular}{|l|l|c|c|c|}
\hline \multirow{2}{*}{$\begin{array}{l}\text { Employees acquainted new skills and knowledge } \\
\text { through training. }\end{array}$} & N & Mean & $\begin{array}{c}\text { Std. } \\
\text { Deviation }\end{array}$ \\
\hline \multirow{2}{*}{$\begin{array}{l}\text { Employees gain adequate training related to their } \\
\text { job and to meet professional standards }\end{array}$} & Public sector & 92 & 3.9022 & .86520 \\
\cline { 2 - 4 } & Private sector & 58 & 4.1034 & .94942 \\
\cline { 2 - 4 } & Public sector & 92 & 3.8370 & .90093 \\
\cline { 2 - 4 } & Private sector & 58 & 4.2759 & .83336 \\
\hline \multirow{2}{*}{$\begin{array}{l}\text { Training and development enhances the efficiency } \\
\text { and effectiveness of the work being performed by } \\
\text { the employees. }\end{array}$} & Public sector & 92 & 3.9239 & 1.01887 \\
\cline { 2 - 4 } & Private sector & 58 & 4.3276 & .68538 \\
\cline { 2 - 4 } $\begin{array}{l}\text { Training and development enhance the quality of } \\
\text { services being performed by employees }\end{array}$ & Total & 150 & 4.0800 & .92337 \\
\cline { 2 - 5 } & Public sector & 92 & 4.1304 & .66659 \\
\cline { 2 - 5 } & Private sector & 58 & 4.3448 & .96521 \\
\hline \multirow{2}{*}{$\begin{array}{l}\text { Progress in incorporating the latest technology into } \\
\text { training and development schedules. }\end{array}$} & Public sector & 92 & 3.8152 & .79922 \\
\cline { 2 - 4 } & Private sector & 58 & 4.1552 & .85433 \\
\cline { 2 - 4 } & Total & 150 & 3.9467 & 1.03487 \\
\hline \multirow{2}{*}{$\begin{array}{l}\text { Training needs identified are realistic, useful and } \\
\text { based on the business strategy of the bank }\end{array}$} & Public sector & 92 & 3.8696 & .97459 \\
\cline { 2 - 4 } & Private sector & 58 & 4.2069 & .78937 \\
\cline { 2 - 4 } & Total & 150 & 4.0000 & .91959 \\
\hline
\end{tabular}


Table 7: ANOVA for Training and Development

\begin{tabular}{|l|l|c|c|c|c|c|}
\hline & & Sum of Squares & df & Mean Square & F & Sig. \\
\hline \multirow{3}{*}{ TD } & Between Groups & 3.386 & 1 & 3.386 & 5.849 & .017 \\
\cline { 2 - 8 } & Within Groups & 85.681 & 148 & .579 & & \\
\cline { 2 - 8 } & \multicolumn{1}{|c|}{ Total } & 89.067 & 149 & & & \\
\hline
\end{tabular}

Source: Primary data

Employees acquainted new skills and knowledge through training is show highest by private sector employees with a mean value of 4.1034 .

Employee's gain adequate training related to their job and to meet professional standards is more in private sector employees with a mean value of 4.2759 .

4.3276 mean value is significantly higher in private sector for the statement 'Training and development enhances the efficiency and effectiveness of the work being performed by the employees'.

Training and development enhance the quality of services being performed by employees of private sector with a mean value of 4.3448 .

Progress in incorporating the latest technology into training and development schedules shows a significant difference between the sectors seeking a higher mean in case of private sector which is 4.1552 .

For the statement 'Training needs identified are realistic, useful and based on the business strategy of the bank'. This too found a significant difference between the sectors .The mean value for Private sector was 4.2069.

As per the above Table no 7 it can be summarized that the Null hypotheses stating that 'There is no significant difference between the employees of public and private sector banks with respect to Training and development' is rejected.

\section{FINDINGS}

The main purpose of the study was to investigate that there is significant difference in the perception of the employees of public and private sector banks with respect to work environment, motivation and training \& development relating to organizational climate.

The obtained data were analyzed in the light of the objectives and hypothesis proposed in the study. For this purpose ANOVA was carried out so that a comparison can be done. The summary of the ANOVA of work environment, motivation and training and development with respect to organizational climate in public and private sector banks have a significant difference. Hence the null hypotheses stating that there is no significant difference between the employees of public and private sector banks with respect to work environment, motivation and training and development is rejected.

\section{CONCLUSIONS}

A sound climate is a long-run scheme. Organizational climate is becoming more important than ever before because organizations need to ensure that those individuals who add value should stay in the organization and continue pouring their efforts into their work to benefit the organization Researchers think that organizational climate is an indirect determinant of behavior in a shared sense. The individual's perceptions of what are "out there" acts as a moderating or dominant variable between organizational provocations and resulting behavior. Organizational climate is the key to business success because it impacts attitudes and behavior of employee's .climate has an important influence on work 
environment, motivation and training and development of the employees. If the climate is favorable, there would be greater organizational effectiveness and leads to healthy atmosphere. The findings leads conclusion that organizational climate of public sector banks and that of private sector banks are different. In the view of above findings, it is concluded that the public sector differs in a good lighting system increases employee's productivity, Controlled noise and temperature in workplace will make an employee to concentrate on their job, Work area has a safe working environment than private sector banks.

\section{REFERENCES}

1. Akhilesh, K.B. and Pandey, S.A., "A Comparative Study of Organizational Climate in Two Banks", Indian Journal of Industrial Relations, 1986, Vol. 21, Issue No. 4

2. Biswas, S.N., "Perceptions of Organizational Climate and Effectiveness: A Comparative Regional Rural Banks," Indian Journal of Industrial Relations, January 1993, Vol. 28, Issue No. 3, pp. 225-37.

3. Bhutto, Niaz Ahmed, Laghari, Minhoon Khanand and Butt, Falah-ud-Din (2012). A comparative study of organizational climate and job satisfaction in public, private and foreign banks. Asian Social Science, 8 (4)

4. Campbellet. (1970). Managerial behaviour, performance, and effectiveness", New York: McGraw-Hill.

5. Dawson. (1987). Computer Technology and the Job of the First-Line Supervisor New Technology. Work

6. Gani.A. and Farooq. A.Shah, "Correlates of organizational climate in banking industry", Indian Journal of Industrial Relations, 2001, p. 36.

7. Gerber, F. (2003). The influence of organizational climate on work motivation. Mcom Dissertation, University of South Africa, Pretoria

8. Hellriegal, D. \& Slocum, J.W., "Organizational Climate: Measures, Research and Contingencies", Academy of Management Journal, 1974, Vol. 17, pp. 255-280.

9. Kothari, C.R., Research Methodology Methods \& Techniques, Wishwa Prakashan, New Delhi, 2003

10. Klien K. J., C. A. (2001). Is everyone in agreement? An exploration of within-group agreement in employee perceptions of the work environment. Journal of applied Psychology, 86, 3-16.

11. Litwin and Stringer, Motivation and Organizational Climate, Cambridge: Harvard University 1968.

12. Newman, "Development of a Measure of Perceived Work Environment (PWE), "Academy of Management Journal 20.4 (1977): $520-534$.

13. Pratap, Swaran and Srivastava, S.K., "Relationship between Job Satisfaction and Organizational Climate; Study of Public Sector: Undertaking in Uttarpradesh", Lok Udyog, 1983, Vol. 17, Issue No.6, pp. 39-43.

14. Purang, P. (2008). Dimensions of HRD climate enhancing organizational commitment in Indian organizations. Indian Journal of Industrial Relations, 43(4), 528-546

15. Rizzati.G.2002."Categories de analise de clima organizacional em universidades federais brasileiras" tese de doutoradoUFSC. Florianopolis, 2002.

16. Schneider. (1983). Work climates: An interactionist perspective", In Feimer, NW \& Geller, ES (Eds.) 1983. Environmental psychology: Directions and perspectives, pp. 106-128.

17. Schneider, B., "Some relationships between Job satisfaction and Organizational Climate", Journal of Applied Psychology, 
1973, pp. 318-323

18. Srivastav. (2009). Heterogeneity of Organizational Climate. Research and Practice in Human Resource Practice, 1-33

19. Woodman, R., \& King, D. (1978). Organizational climate: Science or folklore. Academy of Management Review, 3(4), 816826

20. http://www.ijbmi.org/papers/Vol(2)12/Version-2/B021202012020.pdf

21. http://shodhganga.inflibnet.ac.in/bitstream/10603/33473/7/07_chapter2.pdf 